\title{
Maxillary incisor retraction: Evaluation of different mechanisms
}

\author{
Antônio Carlos de Oliveira Ruellas¹, Matheus Melo Pithon², Rogério Lacerda dos Santos ${ }^{3}$
}

Objective: To mechanically evaluate different systems used for incisors retraction. Methods: Three different methods for incisors retraction using $0.019 \times 0.025$-in stainless steel wire were evaluated. The samples were divided into three groups: Group A (retraction arch with 7-mm high vertical hooks); Group G3 (elastic chain attached to the miniimplant and to the 3-mm stainless steel hook soldered to the retraction arch); Group G6 (elastic chain attached to the mini-implant and to the 6-mm stainless steel hook soldered to the retraction arch). A dental mannequin was used for evaluation in order to simulate the desired movements when the device was exposed to a heat source. The analysis of variance (ANOVA) and the Tukey test were used $(p<0.05)$. Results: The results demonstrated that Groups G3 and G6 exhibited less extrusion and less incisor inclination during the retraction phase $(\mathrm{p}<0.05)$. With regard to incisor extrusion, statistically significant differences were observed between Groups A and G3, and between Groups A and G6 $(p<0.05)$. Regarding incisor inclination, statistically significant differences were observed between the three systems evaluated ( $\mathrm{p}<0.05)$. Conclusions: Arches with $6-\mathrm{mm}$ vertical hooks allow the force to be applied on the center of resistance of the incisors, thus improving mechanical control when compared with the other two systems.

Keywords: Fixed orthodontics. Malocclusion. Maxillary incisors.

Objetivo: avaliar mecanicamente diferentes sistemas utilizados para retração de incisivos. Métodos: três diferentes métodos de retração dos incisivos foram avaliados, utilizando arco ortodôntico de retração confeccionado com fio de aço inoxidável 0,019” x 0,025” de espessura. Os grupos foram divididos em: Grupo A (arco de retração com alças verticais de $7 \mathrm{~mm}$ de altura), Grupo G3 (elástico em cadeia ligado do mini-implante ao gancho de aço inoxidável com $3 \mathrm{~mm}$ de altura soldado no arco de retração) e Grupo G6 (elástico em cadeia ligado do mini-implante ao gancho de aço inoxidável com $6 \mathrm{~mm}$ de altura soldado no arco de retração). Para essa avaliação, adequou-se um manequim odontológico de tal forma que possibilitasse simular os movimentos desejados, quando fosse exposto a uma fonte de calor. Após obtenção das medidas dos movimentos, realizou-se análise estatística. Resultados: os resultados demonstraram que os grupos G3 e G6 propiciaram menor extrusão e menor inclinação palatina dos incisivos na fase de retração $(\mathrm{p}<0,05)$. Quanto à extrusão dos incisivos, houve diferença estatisticamente significativa entre os grupos A e G3, e A e G6 $(p<0,05)$. Em relação à inclinação, ocorreu diferença estatisticamente significativa entre os três sistemas avaliados $(\mathrm{p}<0,05)$. Conclusão: arcos com ganchos verticais de $6 \mathrm{~mm}$ soldados permitem aproximar a linha de ação da força ao centro de resistência dos incisivos, proporcionando melhor controle mecânico, se comparado aos outros dois sistemas.

Palavras-chave: Ortodontia corretiva. Má oclusão. Mecânica.

${ }^{1} \mathrm{MSc}$ and $\mathrm{PhD}$ in Orthodontics, Federal University of Rio de Janeiro UFRJ. Associate Professor of Orthodontics, Federal University of Rio de Janeiro - UFRJ.

${ }^{2}$ Specialist in Orthodontics, Federal University of Alfenas - UNIFAL. MSc and $\mathrm{PhD}$ in Orthodontics, Federal University of Rio de Janeiro - UFRJ. Assistant Professor of Orthodontics, Southwest Bahia State University UESB.

${ }^{3}$ Specialist in Orthodontics, Federal University of Alfenas - UNIFAL. MSc and $\mathrm{PhD}$ in Orthodontics, Federal University of Rio de Janeiro - UFRJ. Associate Professor of Orthodontics, Federal University of Campina Grande - UFCG.
How to cite this article: Ruellas ACO, Pithon MM, Santos RL. Maxillary incisor retraction: Evaluation of different mechanisms. Dental Press J Orthod. 2013 Mar-Apr;18(2):101-7.

Submitted: May 8, 2009 - Revised and accepted: April 12, 2010

» The author reports no commercial, proprietary or financial interest in the products or companies described in this article.

Contact address: Antônio Carlos de Oliveira Ruellas Av. Professor Rodolpho Paulo Rocco, 325 - Ilha do Fundão CEP: 21.941-617 - Rio de Janeiro/RJ - Brazil

E-mail: antonioruellas@yahoo.com.br 


\section{INTRODUCTION}

For many years, orthodontists have sought an efficient force system that is capable of working rapidly, precisely and efficiently in order to shorten the treatment time. On the other hand, it must be known how to control and manipulate this system.

Good control in the retraction of anterior teeth during space closure is essential for successful orthodontic treatment. ${ }^{12,13}$ The incorporation of hooks in the retraction arch allows one to adjust the height of the line of action of the force by means of different lengths of soldered hooks. ${ }^{2,8}$

With the advent of mini-implants, these began to be used as orthodontic anchorage in the retraction of anterior teeth, ${ }^{1}$ in particular, cases that did not allow for anchorage loss have perhaps been the most mentioned indication in the literature, ${ }^{4-7,9,11}$ such as in severe bimaxillary protrusions or Angle's Class II malocclusions to be treated with premolar extractions.

With the purpose of better elucidating the system for maxillary incisor retraction, the aim of this study was to mechanically evaluate different systems used for the retraction of these teeth with and without the use of mini-implants.

\section{MATERIAL AND METHODS}

In order to conduct this experiment, a methodology was developed, in which a Dental mannequin (Prodens F2/PD002, Carapiá Ind. Com. Prod. Odont. LTDA, São Gonçalo, RJ, Brazil), mounted in normal occlusion was used, for the purpose of training undergraduates in Dentistry. Before the experiment was conducted the mannequin was prepared by removing the alveolus to enable the teeth to be moved, thus creating a channel with $2.4 \mathrm{~cm}$ in height and $1.2 \mathrm{~cm}$ wide, which in turn was filled with an utility wax compound (Polidental Ind. Com. LTDA, São Paulo, São Paulo, Brazil) in pink and transparent colors with heat sensitive characteristics. To open the channel, a No. 15 scalpel blade (Solidor, Barueri, São Paulo, Brazil) was used mounted in a scalpel handle and a finishing bur for acrylic resin (H79E 104 040, Komet, Gebr. Brasseler, Lemgo, Germany).

This method was based on Typodont operation routinely used in teaching dentistry students, with the difference that the wax used in the present study was sensitive to the heat produced by an electrical resistance inside a glass chamber, thereby maintaining an environment at $48{ }^{\circ} \mathrm{C}$, and not needing to be submerged in hot water as occurs with regular Typodonts.

Once the mannequin was adapted, the teeth were mounted in a Class I malocclusion, with bimaxillary protrusion. To standardize the malocclusion with the canine already retracted, all teeth (first and second molar, second premolar and canine) were disposed in the same position and referenced on the mannequin base, in addition to teeth intercuspation with their antagonists, since the mandibular arch was identical in all cases.

This malocclusion was chosen due to the fact that the therapy commonly used in these cases is extraction of the first premolars followed by canine and incisor retraction.

After the mannequin was mounted, orthodontic brackets (Dental Morelli LTDA, Sorocaba, São Paulo, Brazil) were bonded according to the edgewise technique, slot $0.022 \times 0.030$-in, which served as support for application of orthodontic mechanics. For bracket placement, individual occlusal positioners were fabricated with Orto Clas acrylic resin (Clássico, São Paulo, SP, Brazil) and $0.021 \times 0.025$-in steel wire (American Orthodontics, Sheboygan, Wisconsin, USA) as a guide. A $5 \mathrm{~mm}$ height (incisal or occlusal surface to the center of the buccal surface) was used for the incisors, canines and premolars, and $4.5 \mathrm{~mm}$ for molars.

After the orthodontic appliance was placed, the mannequin was fixed to a rigid rod. The hole for the mannequin's fixation, located in its posterosuperior part, was fixed to a steel rod $1.0 \mathrm{~cm}$ in diameter and 1.50 meters high, fixed perpendicularly to the ground.

To standardize the mannequin's position parallel to the ground, the upper base and the occlusal plane were projected in the same position and height on the fixation rod. A steel ruler $30 \mathrm{~cm}$ long (Flex-30, Trident Indústria de Precisão LTDA, Itapuí, São Paulo, Brazil) was placed perpendicular to the occlusal plane, for the purpose of measuring incisor extrusion that occurred during retraction.

An orthodontic mini-implant (POT 1618, SIN - Sistema de Implantes, Mooca, São Paulo, Brazil), was inserted $6 \mathrm{~mm}$ from the papilla between the roots of the maxillary first molar and second premolar, in the region of the mucogingival line which, according to Park, ${ }^{10}$ is the site of choice for the insertion of mini-implants destined for the retraction of anterior 
teeth. Three different methods for incisor retraction were evaluated (Fig 1), using an orthodontic retraction arch made with $0.019 \times 0.025$-in stainless steel wire (American Orthodontics, Sheboygan, Wisconsin, USA), thus the groups were divided as follows:

» Group A: Retraction performed with a retraction arch with $7 \mathrm{~mm}$ high vertical loops;

»Group G3: Retraction performed with elastic chain attached to a $3 \mathrm{~mm}$ high stainless steel hook, soldered to the retraction arch, and to a mini-implant;

"Group G6: Retraction performed with elastic chain attached to a $6 \mathrm{~mm}$ high stainless steel hook, soldered to the retraction arch, and to a mini-implant.
The hooks were soldered with silver solder (Dental Morelli LTDA, Sorocaba, São Paulo, Brazil). After soldering, maintenance of the physical-mechanical characteristics of the retraction arches was verified. The angular measurement were obtained by the intersection of the line projected parallel to the mannequin's upper base and long axis of the maxillary right central incisor, before and after incisor retraction (Figs 2, 3 and 5). The linear measurements were obtained starting from a point between the central incisors on the retraction arch, parallel to the palatine raphe up to a line projected perpendicularly in the distal direction of the maxillary second molars.
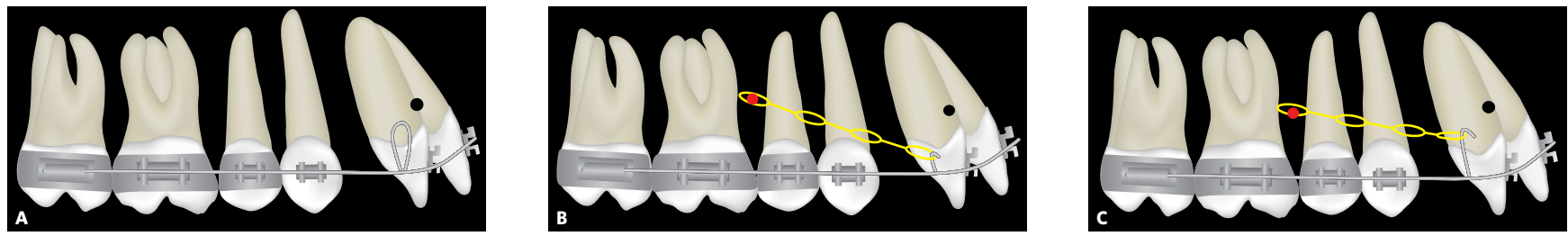

Figure 1 - Photos of the different retraction systems: A) Vertical loop retraction arch; B) Mini-implant and 3-mm soldered hook; C) Mini-implant and 6-mm soldered hook.
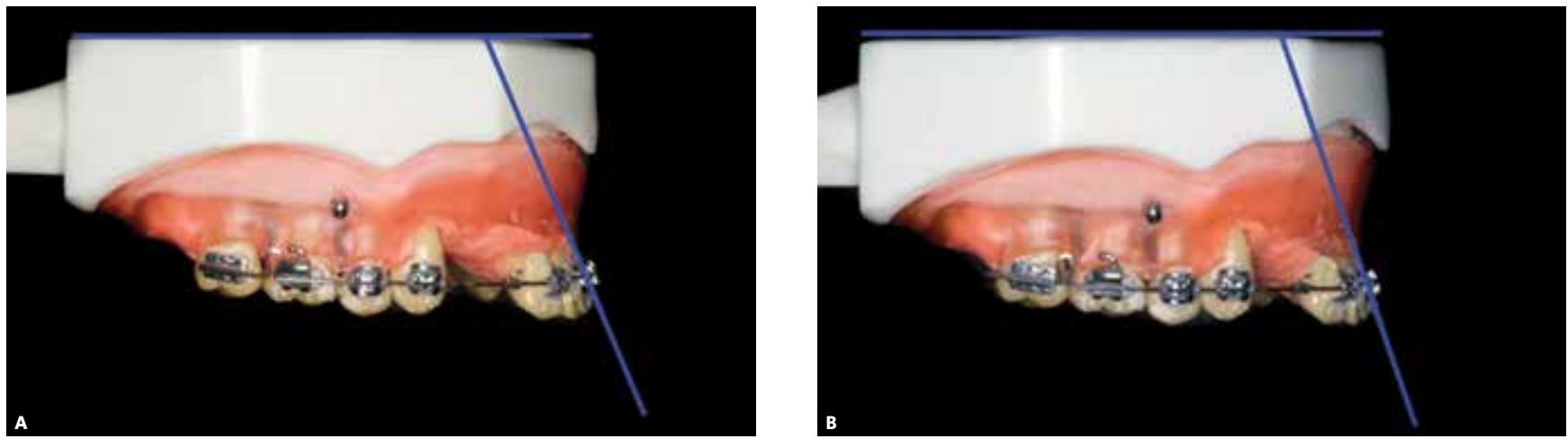

Figure 2 - A) Incisor position before retraction with chain elastics and a 3-mm hook and mini-implant; B) retracted incisors.
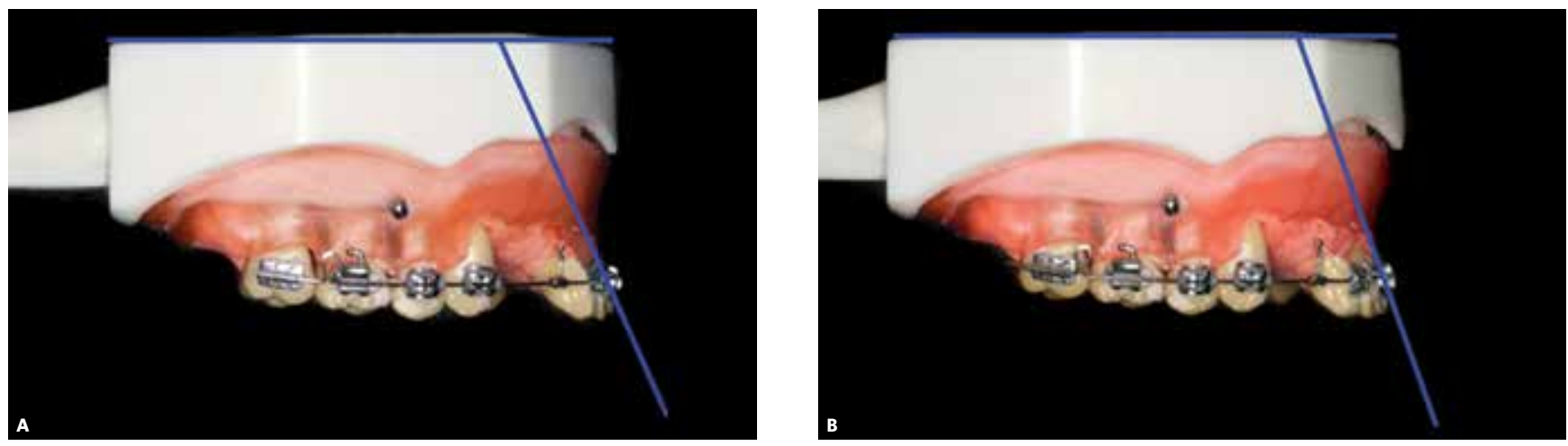

Figure 3 - A) Incisor position before retraction with chain elastics and a 6-mm hook and mini-implant; B) retracted incisors. 


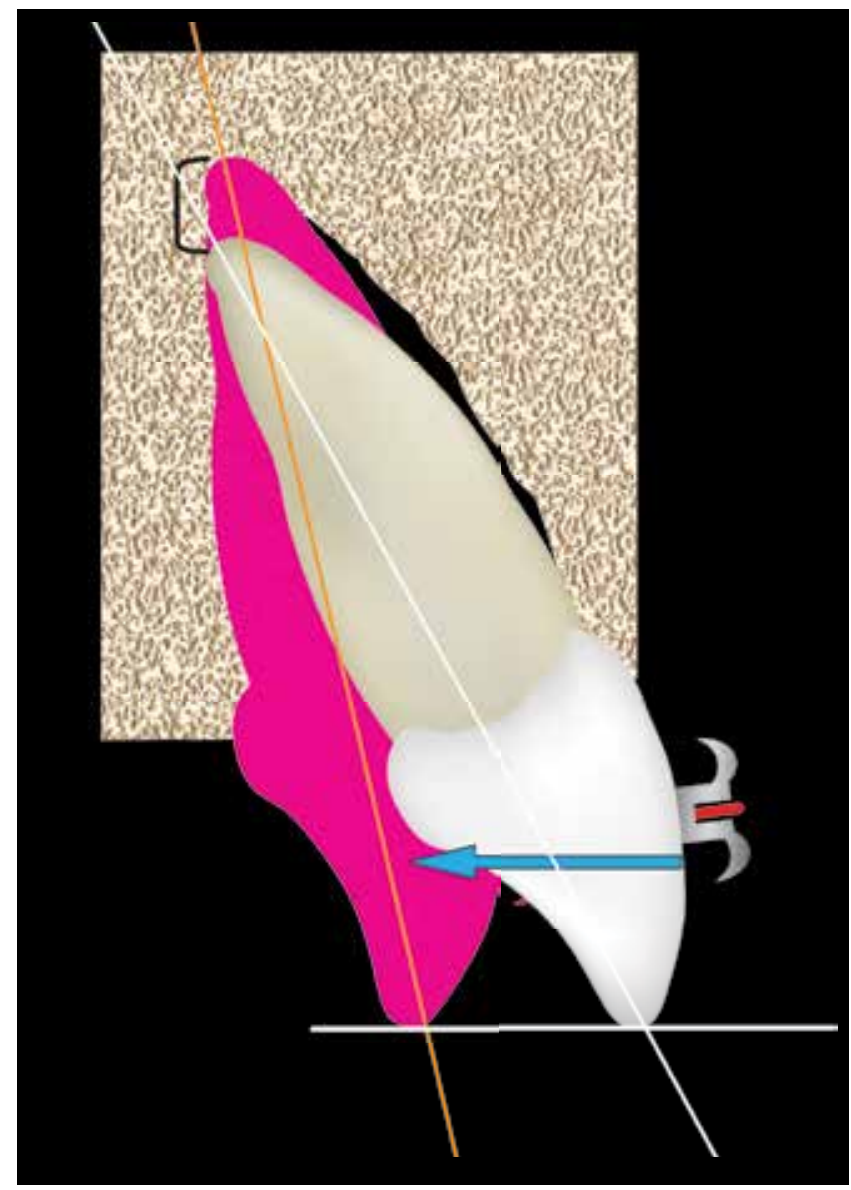

Figure 4 - Illustration of the smallest incisor extrusion and palatal inclination during retraction in the soldered hook groups.

Group A was activated by means of a tieback with metal ligature (mechanics without sliding). Groups G3 and G6 were activated with the use of elastic chains (854-299 Silver, American Orthodontics, Sheboygan, Wisconsin, USA) (sliding mechanics). All the groups were activated with the aid of a dynamometer (Dentaurum 040-711, Ispringen, Germany) with the purpose of activating and standardizing the force measurement (130 gf) necessary for promoting retraction of the teeth, on an average of $1 \mathrm{~mm}$ per minute. The incisors were retracted to an extension of $8 \mathrm{~mm}$, with 15 repetitions being performed in each system, thus enabling the groups to be statistically evaluated. With each new test, the malocclusion was remounted by following all the previously mentioned steps and the position and angulation of the teeth in relation to the upper base, as well as of the teeth in relation to the bottom base of the mannequin were checked.
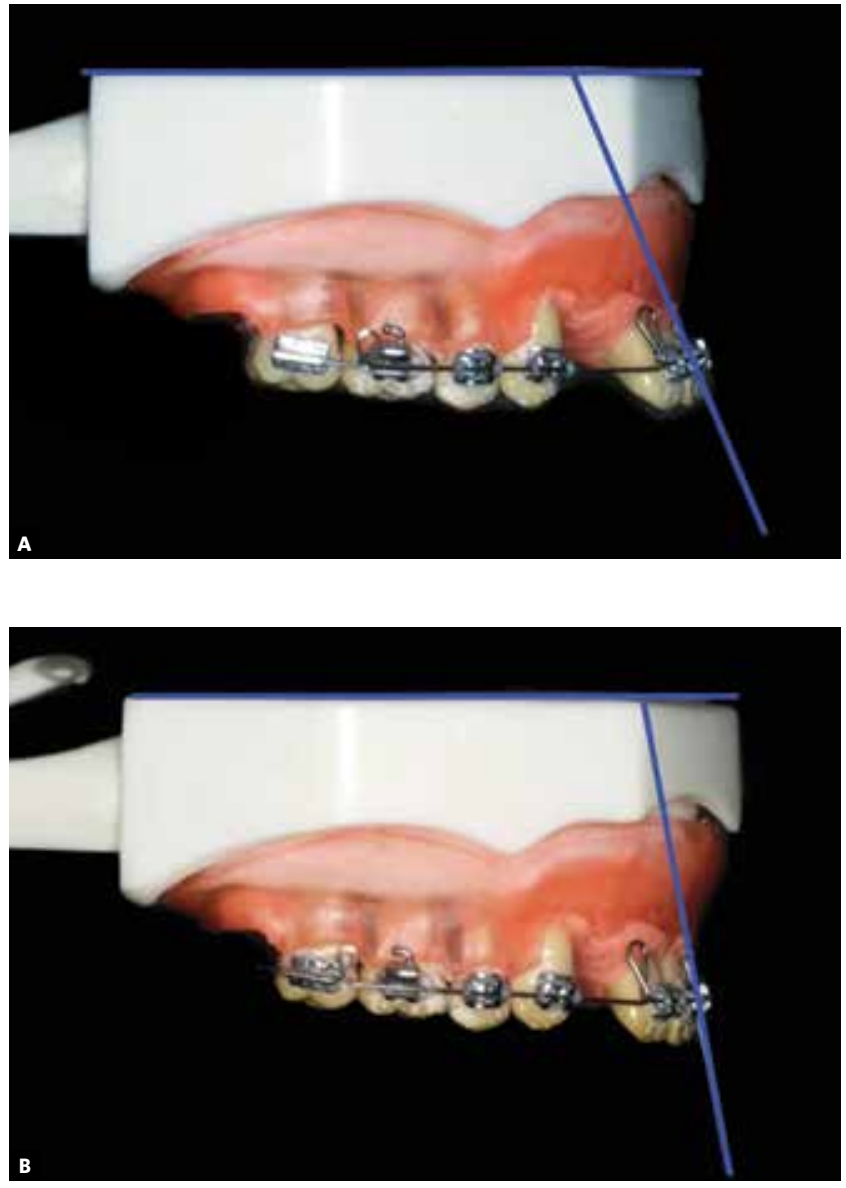

Figure 5 - A) Incisor position before retraction with vertical loops; B) Retracted incisors.

After data collection, statistical analysis was performed with the use of the SPSS 13.0 program (SPSS Inc.,Chicago, Illinois). The values of the amount of extrusion and inclination of the incisors, before and after retraction, obtained in millimeters and angles were submitted to the analysis of variance (ANOVA) to determine whether there were statistical differences among the groups, and afterwards to the Tukey test $(\mathrm{p}<0.05)$.

\section{RESULTS}

The results demonstrated that the system composed of mini-implant / Elastic / hook (Groups G3 and G6) favored less extrusion of the incisors (Table 1) and less palatal inclination (Table 2) of the incisors in the retraction phase $(\mathrm{p}<0.05)$ (Figs 2, 3 and 4$)$. The retraction system with vertical loops activated with tieback ligatures (Group A) favored greater inclination and extrusion of the incisors (Figs 5 and 6) compared with groups G3 and G6. 


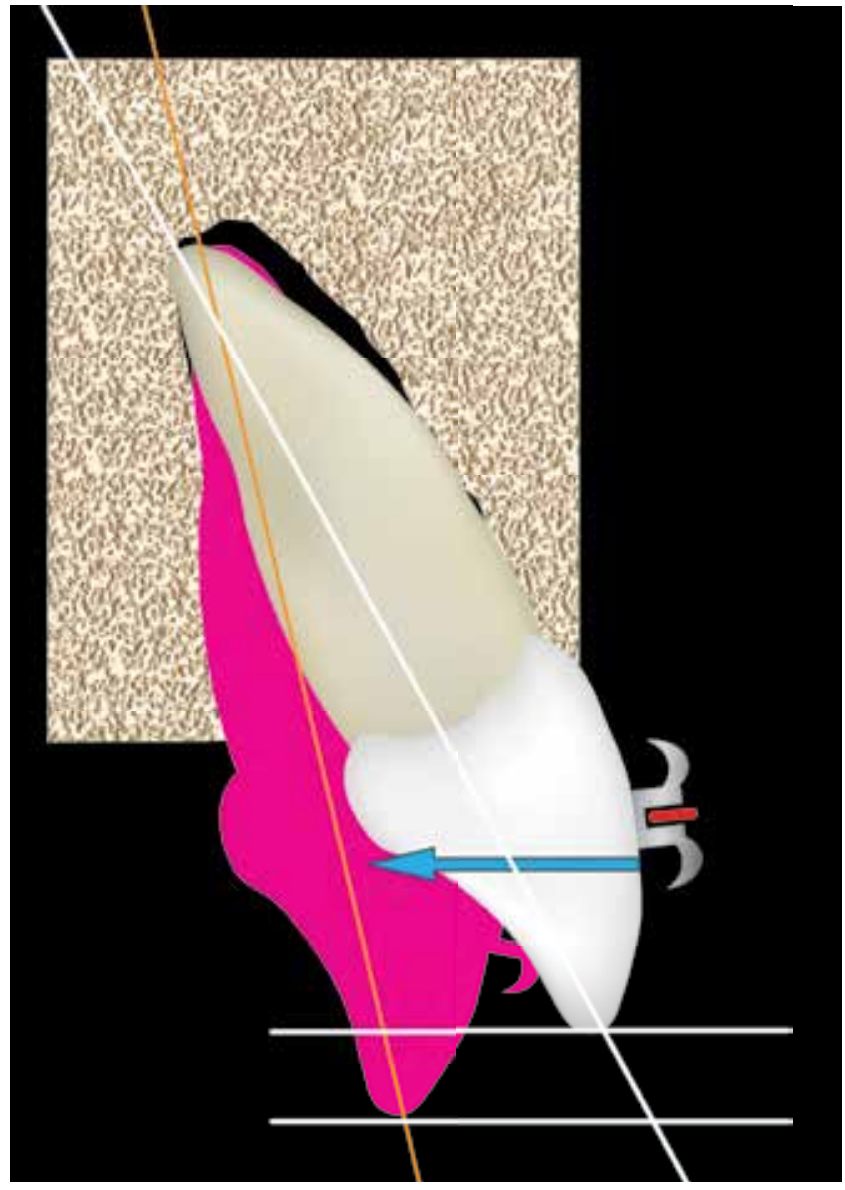

Figure 6 - Illustration of the greatest incisor extrusion and palatal inclination during retraction in the vertical loop group.

As regards extrusion of the incisors, there was statistically significant difference between Groups A and G3, and A and G6 ( $<$ < 0.05), however there was no statistically significant difference between Groups G3 and G6 $(\mathrm{p}>0.05)$ (Table 1).

Regarding inclination, there was statistically significant difference between the three systems evaluated $(\mathrm{p}<0.05)$ (Table 2), however, Group A presented notably greater inclination of the incisors when compared with the other groups (Table 2).

\section{DISCUSSION}

Precise knowledge of the mechanical implications of orthodontic appliances is a decisive factor in the success or failure of treated cases. The retraction stage of anterior teeth is one of the most critical stages of orthodontic treatment, and requires precise mechanical knowledge, thus avoiding undesirable movements and loss of control during treatment.
Table 1 - Values of the amount of extrusion among the evaluated groups.

\begin{tabular}{ccccc}
\hline Groups & n & Mean $(\mathrm{mm})$ & S.D. & Statistical analysis * \\
A & 15 & 2,6 & 0,4 & A \\
G3 & 15 & 0,3 & 0,1 & B \\
\hline G6 & 15 & 0,4 & 0,2 & B \\
\hline
\end{tabular}

* Equal letters indicate absence of statistical differences.

Table 2 - Values of inclination acquired by the incisors after retraction.

\begin{tabular}{ccccc}
\hline Croups & $\mathbf{n}$ & Mean $(\mathrm{mm})$ & S.D. & Statistical analysis * \\
A & 15 & -12 & -5 & A \\
G3 & 15 & -7 & -3 & B \\
G6 & 15 & -2 & -2 & C \\
\hline
\end{tabular}

* Equal letters indicate absence of statistical differences.

Based on this premise, the aim of the present study was to evaluate the mechanical component of three methods of incisor retraction, with the purpose of providing orthodontists with information that they could apply in their daily clinical practice.

With regard to the inclination acquired by the incisors during retraction, Group A showed the greatest amount, followed by Groups G3 and G6, with statistical difference between the groups; that is, the longer the distance from the force to the center of resistance, greater was the inclination acquired by the incisors (Fig 7). In Group A, the moment generated by the torque (lingual root torque) was not sufficient to balance the torque generated by the force (lingual crown torque). This could solved by incorporating active torque on the maxillary incisors (Fig 8). In Groups G3 and G6, in addition to the moment generated by the torque, there is a moment generated by the one-couple system (Fig 9A), due to torsion of the wire in the anterior region as a result of the force applied (Fig 9B) to the hook (the longer the hook, greater the effect). Thus, in Group G6 most movements were practically translation.

Incisor retraction with uprighting results in greater exposure of the incisors in relation to the lip if no mechanical resource is used for vertical control (incisor intrusion).

When the quantity of extrusion acquired by the incisors during retraction was compared, Group A presented greater extrusion than the other groups. This fact may be justified by the vertical position of the line of action of the force, being more distant from the center 


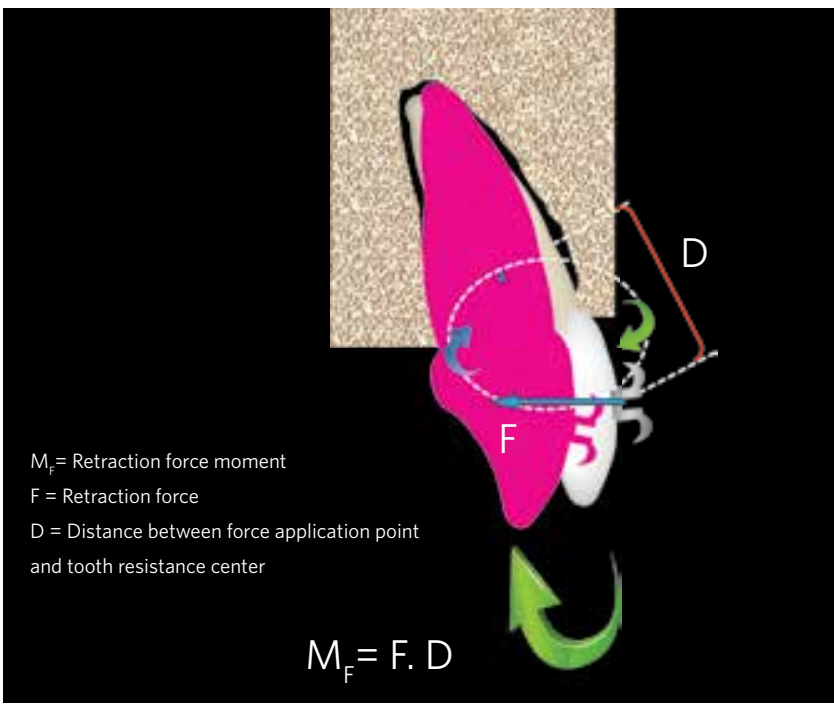

Figure 7 - Illustration of the moment caused by the retraction force.

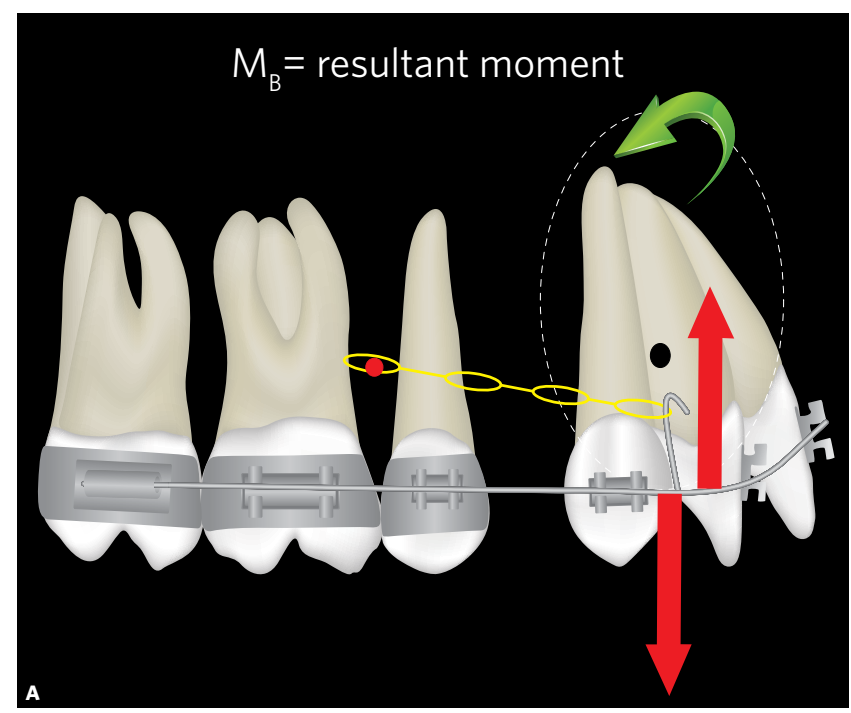

Figure 9 - A) Illustration of the moment generated by both forces due to the archwire torsion in the 6-mm hook group; B) Illustration of the moment generated by the retraction force applied to the $6-\mathrm{mm}$ hook group

of resistance, and consequently increasing incisor inclination (verticalization). It might compromise esthetics with greater exposure of the incisors and a gummy smile, in addition to overbite becoming larger.

Groups G6 and G3 showed no statistical difference between them as regards extrusion. The discrete reduction in extrusion caused in Group G6 in comparison with Group G3 was due to the larger size of the hook, which obtained greater proximity of the line of action of the force with the center of resistance of the anterior segment, which allowed better control of palatal inclination of the incisors.
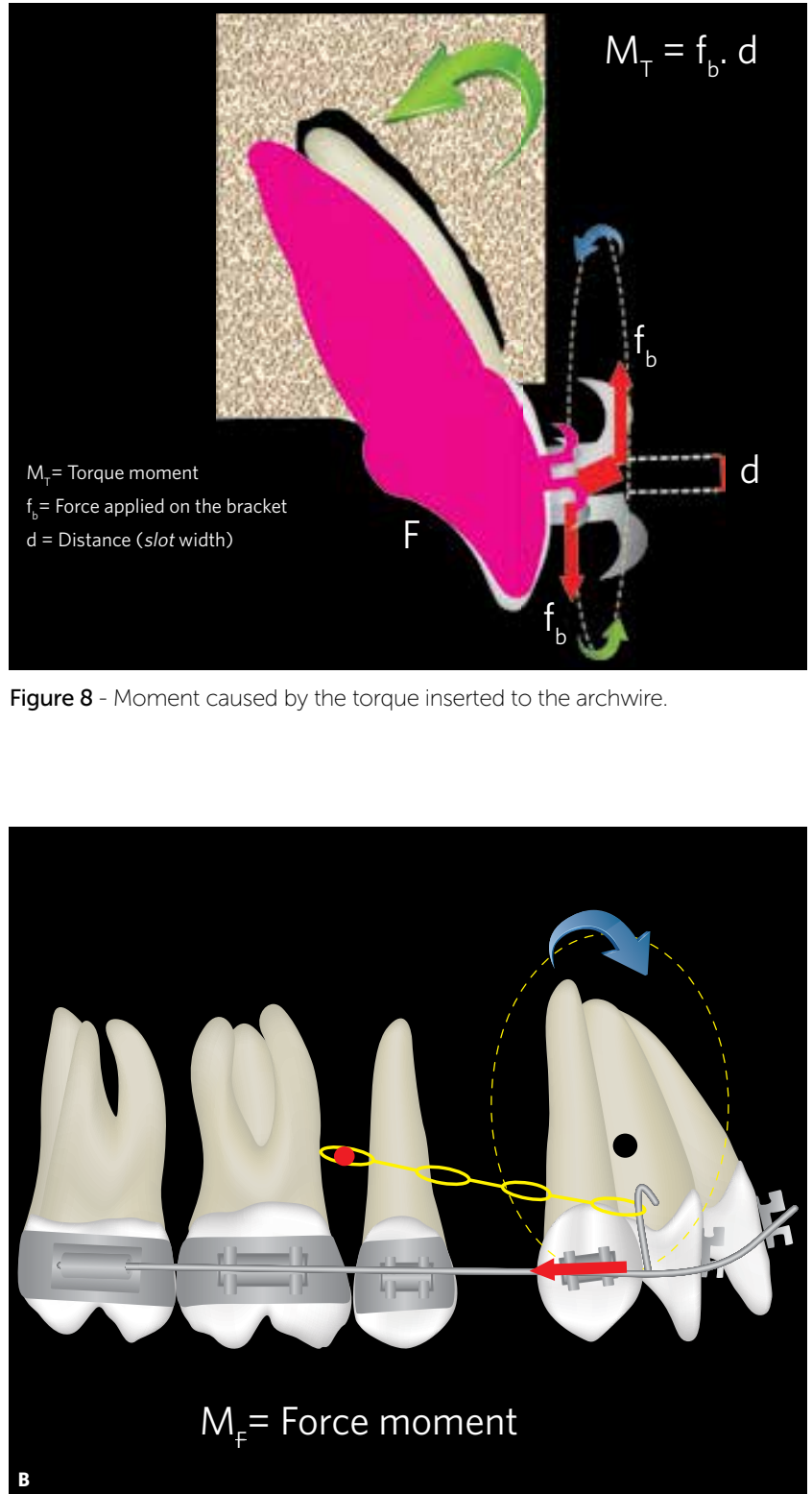

Figure 8 - Moment caused by the torque inserted to the archwire.

Thus, the closer the force's line of action to the center of resistance, greater the extrusion control.

The findings of this study are in agreement with analyses proposed by Burstone, ${ }^{2}$ Burstone and Pryputniewicz. ${ }^{3}$ They showed that the center of rotation moved apically from the center of the root as the height of force application was raised in the direction of the apex. When the height of force application was above the center of resistance in the incisal direction, the center of rotation was displaced in the incisal direction, thus tooth inclination and extrusion would depend on the direction of force application. 
It may be observed that the different systems presented distinct lines of action of force, and that their relationship with the center of resistance of the incisors showed different intensities of angular and linear movements. As the height of force application was displaced in the apical direction, as in Group G6, the center of rotation was also displaced in the same direction.

Clinically, it becomes important to approximate the line of action of force to the center of resistance of the tooth to the maximum extent whenever possible. Among the resources for this purpose, one could bond accessories in a more cervical direction, using longer hooks soldered to the arch or to the distal wing of the bracket, or the use of sliding jigs.

The group with the $6 \mathrm{~mm}$ hook presented better results probably due to the fact that the system produced more bodily movement (translation) than palatal inclination, however the greater difficulty in moving the root in the distal direction simultaneously to the crown, probably requires a longer retraction time, or greater force application.

\section{CONCLUSIONS}

By conducting this study, it could be concluded that: " Arches with vertical $6 \mathrm{~mm}$ high soldered hooks allowed approximation of the line of action of force to the center of resistance of the incisors, providing better mechanical control.

»Association of palatal torque on the retraction arches of anterior teeth is suggested to increase vertical control and diminish the palatal inclination of the incisors during the movement of retraction.
1. Araújo TM, Nascimento MHA, Bezerra F, Sobral MC. Ancoragem esquelética em Ortodontia com miniimplantes. Rev Dental Press Ortod Ortop Facial. 2006:11(4):126-56

2. Burstone CJ. Application of bioengineering to clinical orthodontics. In: Graber TM, Swain BF, editors. Orthodontics, current principles and techniques. St.Louis: Mosby; 1985. p. 193-228.

3. Burstone CJ, Pryputniewicz RJ. Holographic determination of centers of rotation produced by orthodontic forces. Am J Orthod. 1980:77(4):396-409.

4. Carano A, Velo S, Leone P, Siciliani G. Clinical applications of the miniscrew anchorage system. J Clin Orthod. 2005:39(1):9-24.

5. Chung KR, Kim SH, Kook YA. The C-orthodontic micro-implant. J Clin Orthod. 2004:38(9):478-86

6. Gray JB, Smith R. Transitional implants for orthodontic anchorage. J Clin Orthod. 2000:34(11):659-66

7. Marassi CEA. O uso de miniimplantes como auxiliares do tratamento ortodôntico. Ortodontia SPO. 2005:38(3):256-65.
8. Nanda R, Ghosh J. Biomechanical considerations in sliding mechanics In: Nanda R, editor. Biomechanics in clinical orthodontics. Philadelphia: W. B. Saunders; 1997. p. 188-217.

9. Paik CH, Woo YJ, Boyd RL. Treatment of an adult patient with vertical maxillary excess using miniscrew fixation. J Clin Orthod. 2003:37(8):423-8

10. Park HS. An anatomical study using CT images for the implantation of micro-implants. Korea J Orthod. 2002;32(6):435-41.

11. Park HS, Kwon OW, Sung JH. Microscrew implant anchorage sliding mechanics. World J Orthod. 2005:6(3):265-74

12. Sia S, Koga Y, Yoshida N. Determining the center of resistance of maxillary anterior teeth subjected to retraction forces in sliding mechanics. An in vivo study. Angle Orthod. 2007;77(6):999-1003.

13. Sia S, Shibazaki T, Koga Y, Yoshida N. Experimental determination of optimal force system required for control of anterior tooth movement in sliding mechanics. Am J Orthod Dentofacial Orthop. 2009;135(1):36-41 